Article

\title{
Acetylharpagide Protects Mice from Staphylococcus Aureus-Induced Acute Lung Injury by Inhibiting NF-kB Signaling Pathway
}

\author{
Zhaoxin Zhang, Yun Wang, Yating Shan and Wu Yin * \\ The State Key Lab of Pharmaceutical Biotechnology, College of life Sciences, Nanjing University, Nanjing 210023, \\ China; zhaoxinzhang1989@126.com (Z.Z.); wy1803556196@163.com (Y.W.); shanyating340303@126.com (Y.S.) \\ * Correspondence: wyin@nju.edu.cn; Tel.:+86-139-1476-1940
}

Received: 8 October 2020; Accepted: 24 November 2020; Published: 25 November 2020

\begin{abstract}
Staphylococcus aureus (S. aureus)-induced acute lung injury (ALI) is a serious disease that has a high risk of death among infants and teenagers. Acetylharpagide, a natural compound of Ajuga decumbens Thunb. (family Labiatae), has been found to have anti-tumor, anti-inflammatory and anti-viral effects. This study investigates the therapeutic effects of acetylharpagide on S. aureus-induced ALI in mice. Here, we found that acetylharpagide alleviated S. aureus-induced lung pathological morphology damage, protected the pulmonary blood-gas barrier and improved the survival of S. aureus-infected mice. Furthermore, S. aureus-induced myeloperoxidase (MPO) activity of lung homogenate and pro-inflammatory factors in bronchoalveolar lavage (BAL) fluid were suppressed by acetylharpagide. Mechanically, acetylharpagide inhibited the interaction between polyubiquitinated receptor interacting protein 1 (RIP1) and NF-kB essential modulator (NEMO), thereby suppressing NF- $\mathrm{kB}$ activity. In summary, these results show that acetylharpagide protects mice from S. aureus-induced ALI by suppressing the NF- $\mathrm{kB}$ signaling pathway. Acetylharpagide is expected to become a potential treatment for S. aureus-induced ALI.
\end{abstract}

Keywords: acute lung injury; Staphylococcus aureus; acetylharpagide; NF-кB signaling

\section{Introduction}

Acute lung injury (ALI) is caused by severe infection, trauma and sepsis, and is mainly shown as non-cardiogenic pulmonary edema, progressive dyspnea and refractory hypoxemia [1,2]. In some circumstances, ALI deteriorates into acute respiratory distress syndrome (ARDS) [3]. After years of basic and clinical research, the diagnosis and treatment of ALI are improving day by day. However, due to its complicated pathogenesis and poor treatment effect, the mortality rate still remains high. It is generally considered that microbial infection is the main cause of ALI [4]. Staphylococcus aureus (S. aureus) is regarded as a highly infectious Gram-positive bacterium for ALI $[5,6]$. S. aureus infection activates the host's immune system, causing infiltration of inflammatory cells (like neutrophils and macrophages), inducing expression of cytokines and chemokines, leading to uncontrollable inflammatory response [7]. Many studies have found that excessive lung inflammation was the main cause of ALI and alleviating inflammation was an effective way to treat ALI [8-10]. Recently, many studies have reported that traditional Chinese medicines, such as Scutellaria baicalensis, Lonicera japonica, Ajuga decumbens and Forsythia suspensa can effectively relieve inflammation and defense against infection [11-14].

Ajuga decumbens Thunb. (family Labiatae) is a common traditional Chinese medicine for dispelling internal heat and toxic material. It can be used for respiratory tract infections, such as tonsillitis, pharyngitis and bronchitis [15]. Its active ingredients have many biological effects such as anti-inflammatory, bacteriostatic, immune function regulation, anti-fibrosis, anti-tumor and so 
on $[16,17]$. Acetylharpagide is one of the wonderful active ingredients derived from Ajuga decumbens and was first discovered to have vasoconstrictive activity in guinea pig [18]. Recently, some studies have reported that acetylharpagide had outstanding antibacterial, anti-inflammatory, and antiviral activities [19-21]. However, the effects of acetylharpagide on S. aureus-induced pneumonia are still unclear.

Acetylharpagide is one of the active ingredients derived from Ajuga decumbens [13,18-21], a common traditional Chinese medicine for dispelling internal heat and toxic material [15]. Its chemical formula is $\mathrm{C}_{17} \mathrm{H}_{26} \mathrm{O}_{11}$ and its structure was drawn with chemdraw software (Figure 1). Acetylharpagide is a member of ridoid glycosides. Iridoid glycosides are usually divided into nine-carbon skeleton iridoid glycoside type, ten-carbon skeleton iridoid glycoside type and secoiridoid glycoside type. Acetylharpagide belongs to the nine-carbon skeleton iridoid glycoside type (Figure 1). Iridoid glycosides are one of the most common ingredients in traditional Chinese medicines. For example, the well-known iridoid glycosides geniposide, catalpol, picroside II and gentiopicroside/gentiopicrin are the indicator components of traditional Chinese medicines Gardenia jasminoides, Rehmannia glutinosa, Picrorhiza scrophulariiflora and Gentiana scabra, respectively [22-25]. Iridoid glycosides have a wide range of pharmacological effects, the most prominent of which is anti-inflammatory activity [26-28]. Studies have found that the anti-inflammatory effects of iridoid glycosides are mostly related to the NF- $\kappa \mathrm{B}$ pathway and the mitogen-activated protein kinase (MAPK) pathway. Yu et al. found geniposide that was isolated from Gardenia jasminoides attenuated S. aureus-induced pneumonia by supressing NF- $\mathrm{B}$ activation [29]. He et al. found that scandoside isolated from Hedyotis diffusa reduced inflammation by blocking NF- $\mathrm{B}$ and MAPK signaling pathways in lipopolysaccharide (LPS)-stimulated macrophages [30]. Liang et al. found that gardenoside had a protective effect on free fatty acid-induced steatosis in HepG2 hepatocytes, and the mechanism may be to reduce the secretion of pro-inflammatory factors by inhibiting intracellular NF- $\mathrm{KB}$ activity [31].

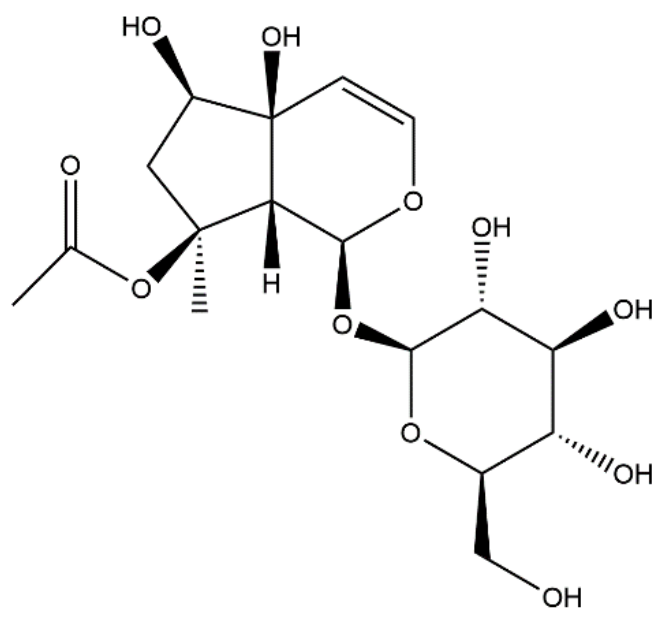

Figure 1. The chemical structure of acetylharpagide.

In this study, we found that acetylharpagide relieved S. aureus-induced pneumonia and lung injury, and improved the survival of S. aureus-infected mice. Mechanically, acetylharpagide inhibited the interaction between polyubiquitinated receptor interacting protein 1 (RIP1) and NF- $\mathrm{k}$ B essential modulator (NEMO), thereby inhibiting NF-kB activity and cytokine production. In summary, acetylharpagide protects mice from $S$. aureus-induced pneumonia and lung injury by suppressing NF- $\mathrm{B}$ signaling pathways and acetylharpagide is expected to become a potential treatment for S. aureus-induced ALI. 


\section{Results}

\subsection{Acetylharpagide Protects Mice from S. aureus-Induced ALI}

Many studies have reported that acetylharpagide has outstanding antibacterial, anti-inflammatory and antiviral activities [19-21]. To explore whether acetylharpagide takes part in S. aureus-induced ALI and how it works, we established the ALI mice model infected with $S$. aureus. Mice were inoculated $S$. aureus directly into the trachea and intraperitoneally injected with $5 \mathrm{mg} / \mathrm{kg}, 10 \mathrm{mg} / \mathrm{kg}, 20 \mathrm{mg} / \mathrm{kg}$ or $40 \mathrm{mg} / \mathrm{kg}$ of acetylharpagide $2 \mathrm{~h}$ prior to $S$. aureus infection. We found that acetharpagide improved the survival rate of $S$. aureus infected mice (Figure $2 a$ ). Within a certain range, the improved effect gradually enhanced with the increase of dose, of which $20 \mathrm{mg} / \mathrm{kg}$ had the best effect. S. aureus infection significantly increased the bacterial loads in the lungs, but acetharpagide seemed to have no effect on bacterial clearance (Figure $2 b$ ). Hematoxylin and eosin (H\&E) staining showed that after S. aureus infection, the alveolar walls were thickened, broken or even collapsed, and many inflammatory cells infiltrated in the alveolar cavity. There was obvious edema and hyperemia around the bronchi, and accumulation of edema fluid could be seen in the alveolar cavity. Acetylharpagide pretreatment reduced S. aureus-induced lung damage, and the effect gradually enhanced with the increase of dose. The lung tissue structure was clear, the alveolar wall was not thickened and the infiltration of inflammatory cells and the accumulation of edema fluid in the alveolar cavity were reduced (Figure 2c). Thus, these results suggest that acetylharpagide protects mice from $S$. aureus-induced ALI.

(a)

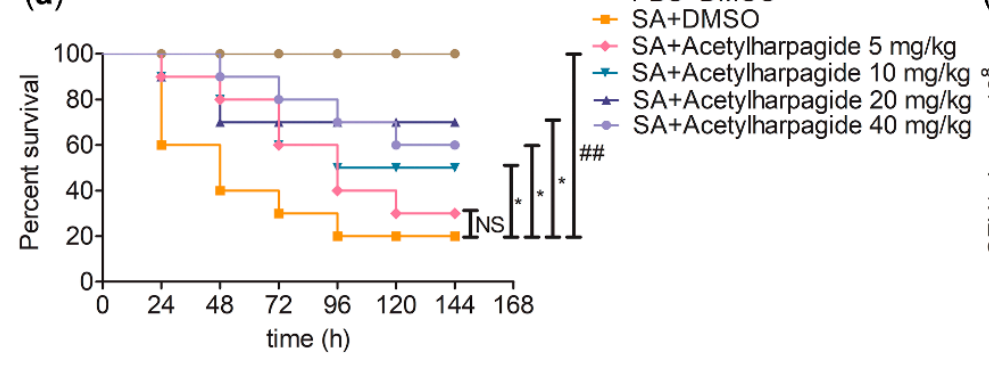

(b)

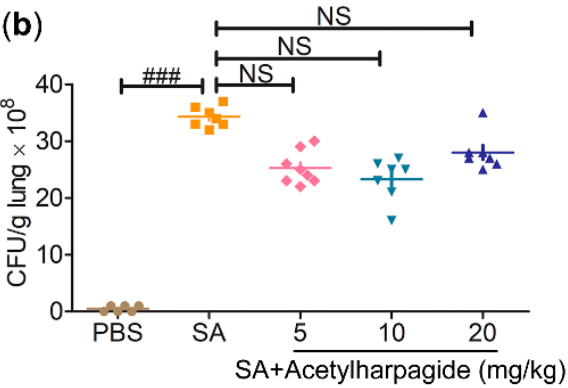

(c)

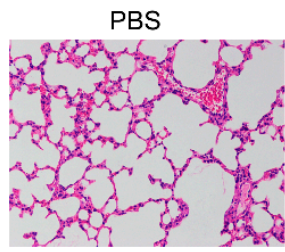

SA+Acetylharpagide $(\mathrm{mg} / \mathrm{kg})$
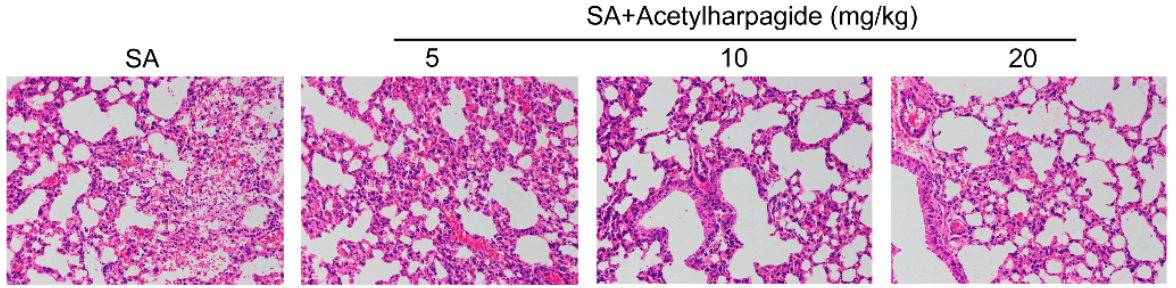

Figure 2. Acetylharpagide protected mice from Staphylococcus aureus (SA)-induced acute lung injury (ALI). (a) Acetylharpagide was injected intraperitoneally daily from day 0 to 5 . The survival of S. aureus-infected mice with or without acetylharpagide was recorded. Kaplan-meier curves and log rank test were used to compare mortality rates, ${ }^{\# \#} p<0.01$ vs. phosphate buffered saline (PBS)+DMSO group, ${ }^{*} p<0.05$ vs. SA+DMSO group, $n=10$; (b) The bacterial loads of the lung homogenate were measured at $12 \mathrm{~h}$ after $S$. aureus infection. The data were presented as mean $\pm \mathrm{SD},{ }^{\# \#} p<0.001 \mathrm{vs}$. PBS+DMSO group, $n=6-8$; (c) Hematoxylin and eosin staining of mouse lung tissues that infected with $S$. aureus for $12 \mathrm{~h}, \times 200$.

\subsection{Acetylharpagide Protects the Pulmonary Blood-Gas Barrier in S. aureus-Induced ALI}

The pulmonary gas-blood barrier is a membrane that is used to exchange oxygen in the alveoli and carbon dioxide in the capillaries of the lungs. Its integrity is critical to gas exchange and to prevent the backflow of substances from the blood into the interstitial and alveolar cavities. The destruction of its integrity would result in increased permeability and pulmonary edema, which are the core pathological changes of ALI [32]. In our study, lung wet/dry ratio was examined to evaluate lung 
water content, and the concentration of evans blue dye in the lung tissue and the total protein in bronchoalveolar lavage (BAL) fluid were determined to evaluate vascular leak (Figure 3). We found that mice infected with $S$. aureus showed increased lung wet/dry ratio (Figure 3a), elevated total protein concentration in BAL fluid (Figure 3b) and aggravated evans blue dye extravasation (Figure 3c). However, acetylharpagide pretreatment significantly attenuated pulmonary edema and vascular leakage, and the effect gradually enhanced with the increase of dose (Figure 3). Thus, these results suggest that acetylharpagide protects the pulmonary blood-gas barrier in S. aureus-induced ALI.

(a)

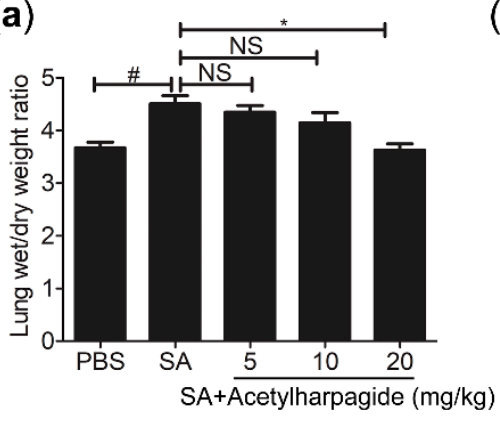

(b)

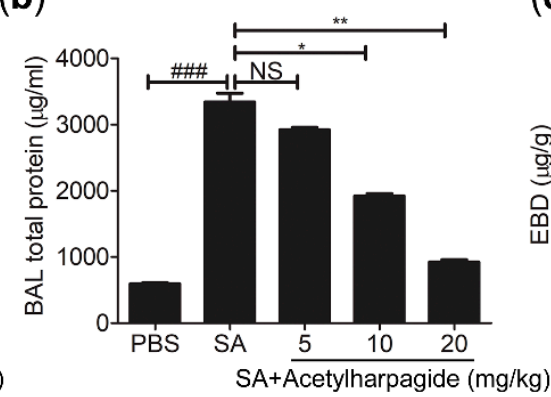

(c)

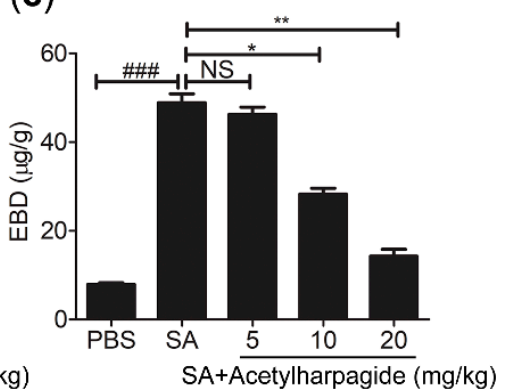

Figure 3. Acetylharpagide relieved S. aureus (SA)-induce pulmonary vascular permeability and edema. (a) The lung wet/dry ratio was detected at $12 \mathrm{~h}$ after S. aureus infection; (b) Bronchoalveolar lavage (BAL) fluid was collected at $12 \mathrm{~h}$ after $S$. aureus infection and bicinchoninic acid (BCA) protein assay was performed to measure the total protein concentration; (c) The concentration of evans blue dye (EBD) in the lung tissue was examined at $12 \mathrm{~h}$ after $S$. aureus infection. The data were presented as mean $\pm \mathrm{SD},{ }^{\#} p<0.05,{ }^{\# \# \#} p<0.001$ vs. PBS+DMSO group, ${ }^{*} p<0.05,{ }^{* *} p<0.01$ vs. SA+DMSO group, $n=6-8$.

\subsection{Acetylharpagide Attenuates S. aureus-Induced Inflammation}

In the process of $S$. aureus infection, neutrophil is one of the most important members of the innate immune system, and it is also one of the first effector cells recruited to the inflammatory area to exert immune defense [33]. Neutrophil contains a large amount of cytotoxic substances. Although these cytotoxic substances can kill pathogenic microorganisms, they may also aggravate inflammatory reactions and lung injury [34]. We found that in the BAL fluid of S. aureus-infected mice, total cells and neutrophils had greatly increased, and the majority of the total cells were neutrophils. However, acetylharpagide pretreatment reduced the number of total cells and neutrophils in BAL fluid that induced by $S$. aureus infection (Figure $4 a, b$ ), and the effect gradually improved with the increase of dose. Consistently, myeloperoxidase (MPO) activity, a marker indicating the degree of neutrophil infiltration, was elevated in S. aureus-infected mice, but decreased by acetylharpagide pretreatment (Figure 4c). Enzyme-linked immunosorbent assays (ELISA) results revealed that $S$. aureus-induced cytokines TNF- $\alpha$, IL-6, TGF- $\beta$, MCP-1, MIP-2 and IL-1 $\beta$ in BAL fluid were also reduced by acetylharpagide pretreatment, and the effect gradually improved with the increase of dose (Figure $4 \mathrm{~d}-\mathrm{i}$ ). Thus, these results suggest that acetylharpagide attenuates $S$. aureus-induced inflammation. 
(a)
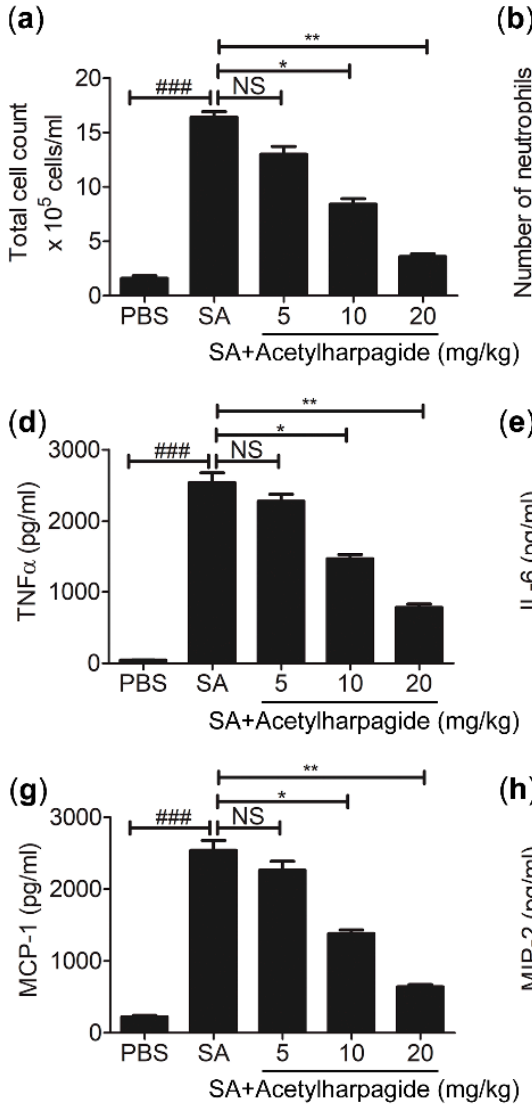

(b)

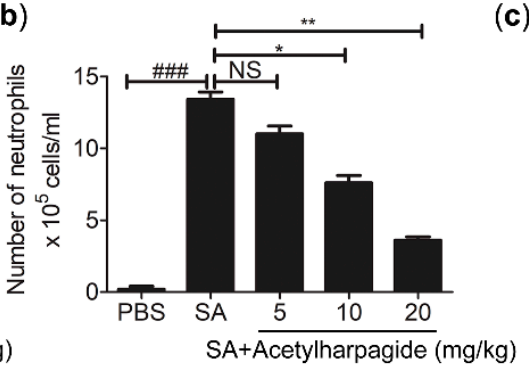

(c)

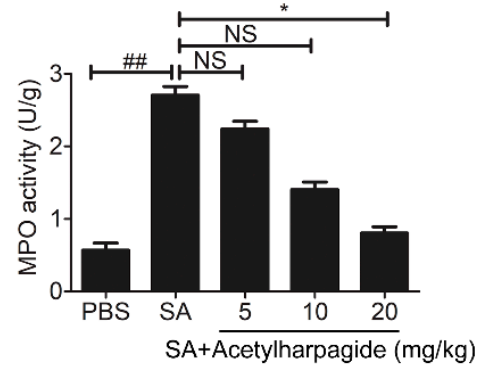

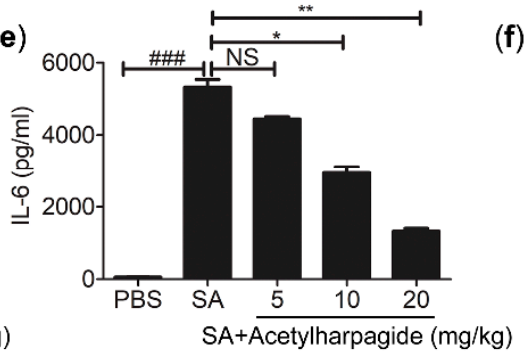
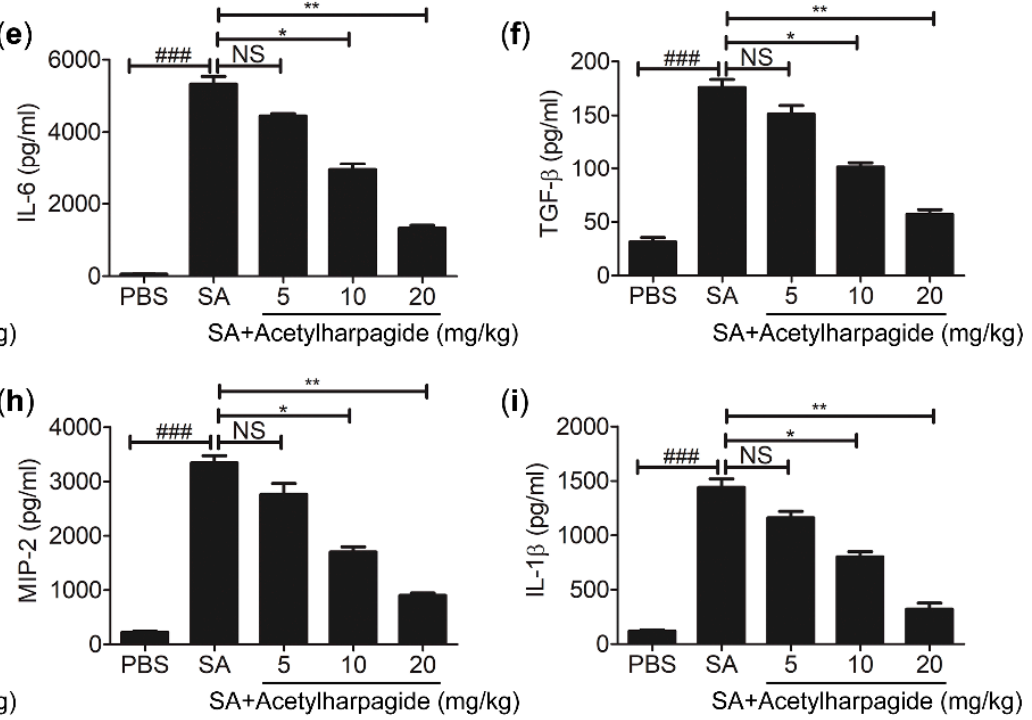

Figure 4. Acetylharpagide attenuated S. aureus (SA)-induced inflammation. (a,b) The number of total cells and neutrophils in BAL fluid were counted at $12 \mathrm{~h}$ after $S$. aureus infection; (c) The myeloperoxidase (MPO) activity of lung homogenate was measured by ELISA at $12 \mathrm{~h}$ after $S$. aureus infection; (d-i) ELISA was performed to measure the concentrations of TNF- $\alpha$ (d), IL-6 (e), TGF- $\beta$ (f), MCP-1 (g), MIP-2 (h) and IL-1 $\beta$ (i) in BAL fluid at $12 \mathrm{~h}$ after $S$. aureus infection. The data were presented as mean \pm SD, \#\# $p<0.01,{ }^{\# \#} p<0.001$ vs. PBS+DMSO group, ${ }^{*} p<0.05,{ }^{* *} p<0.01$ vs. SA+DMSO group, $n=6-8$.

\subsection{Acetylharpagide Inhibits S. aureus-Induced Pro-Inflammatory Cytokines in Macrophages}

Macrophages are an essential member of the innate immune system and play important roles in cytokine secretion and pathogen elimination [35]. To study the anti-inflammatory mechanisms of acetylharpagide against S. aureus infection, we cultured Raw264.7 cells (mouse leukemia cells of monocyte macrophage) in vitro. Cells were pretreated with acetylharpagide or DMSO followed by $S$. aureus infection. The culture medium was harvested for determining the concentration of cytokines. ELISA results revealed that $S$. aureus-induced cytokines IL-1 $\beta$, MCP-1, TNF- $\alpha$, MIP-2, IL- 6 and TGF- $\beta$ were decreased by acetylharpagide pretreatment. The inhibitory effect gradually enhanced with the increase of dose, and reached a maximum at $10 \mu \mathrm{M}$ (Figure 5a-f). Consistently, acetylharpagide pretreatment inhibited the mRNA expression of these pro-inflammatory factors in Raw264.7 cells (Figure 5g-1). Thus, these results predict that acetylharpagide inhibits S. aureus-induced pro-inflammatory cytokines in macrophages. 
(a)
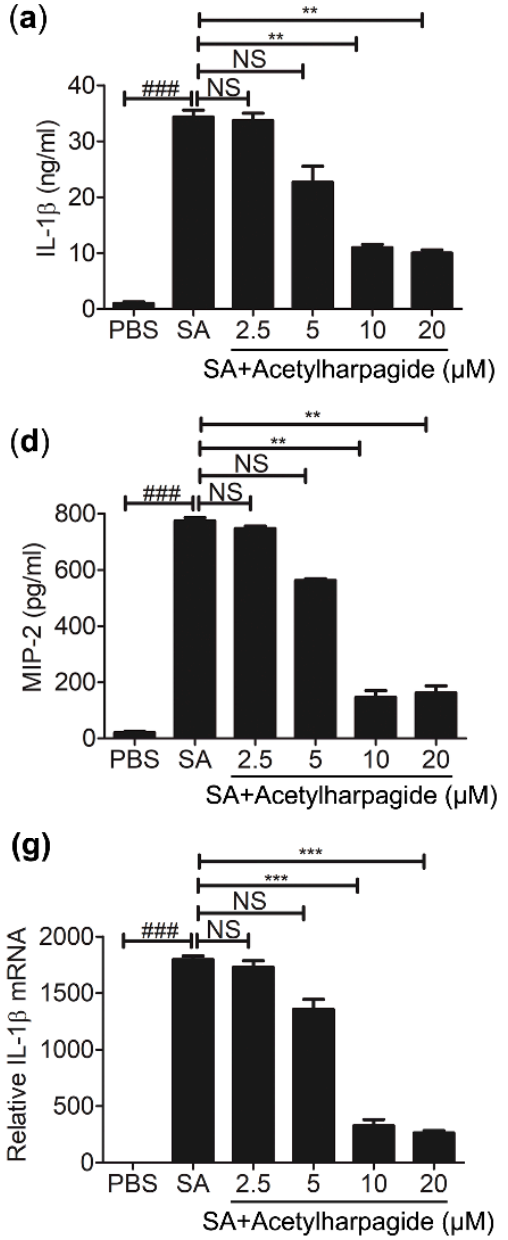

(j)

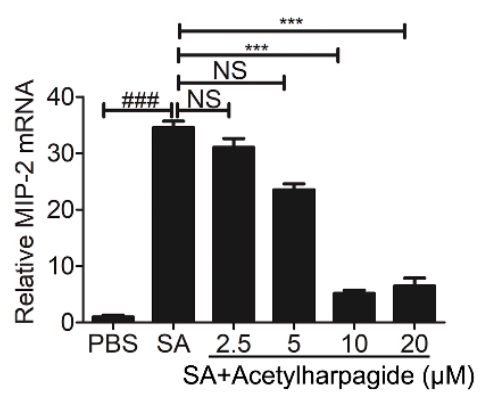

(b)

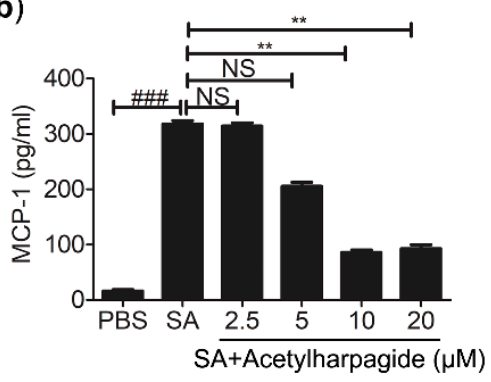

(e)

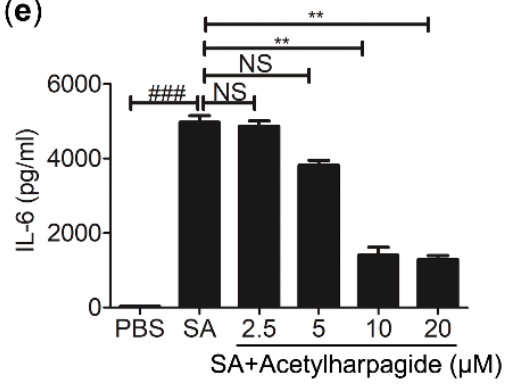

(h)

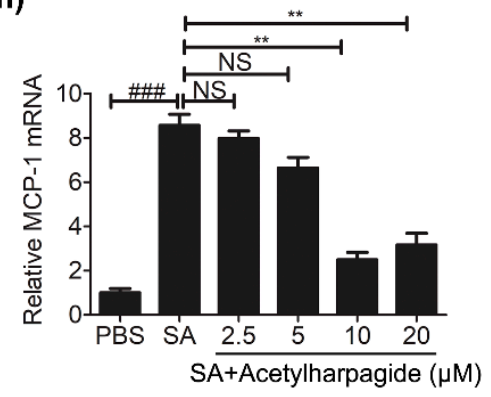

(k)

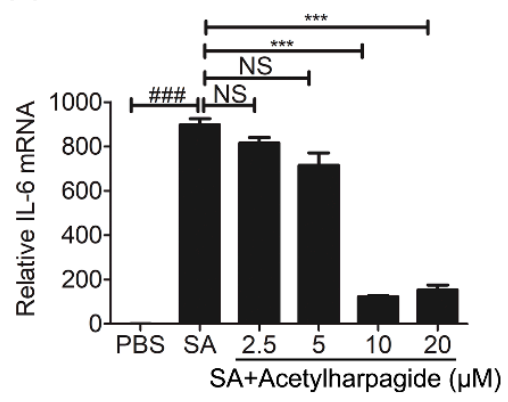

(c)

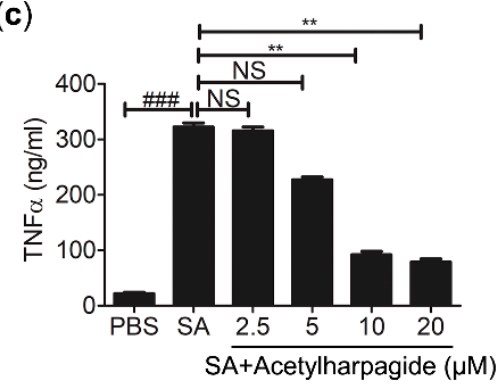

(f)

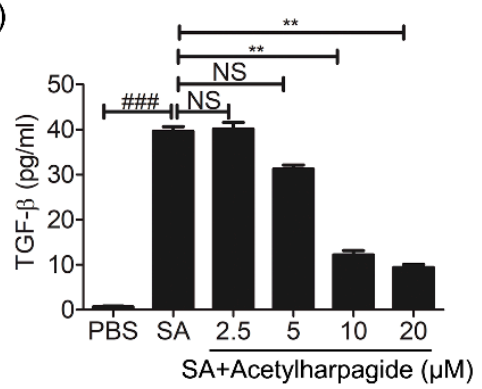

(i)

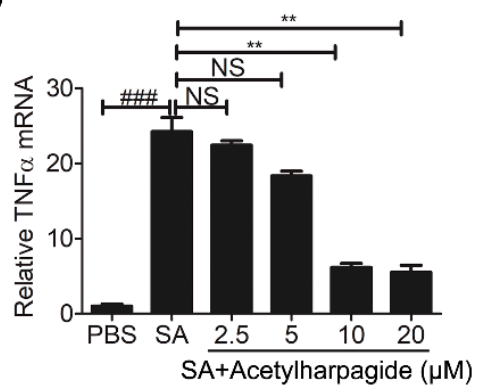

(I)

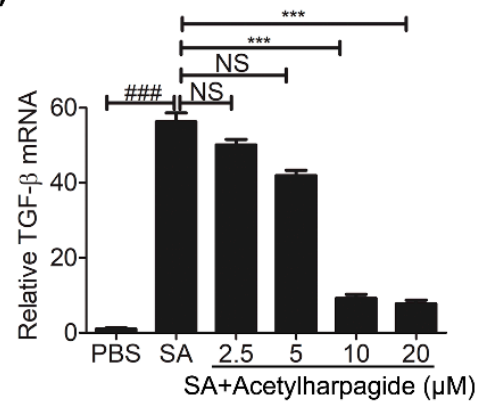

Figure 5. Acetylharpagide inhibited S. aureus (SA)-induced pro-inflammatory cytokines in macrophages. Raw264.7 cells were pretreated with acetylharpagide or DMSO for $2 \mathrm{~h}$, then stimulated with S. aureus (multiplicity of infection (MOI), 10:1) for $2 \mathrm{~h}$. (a-f) The culture medium was harvested and determined for the concentrations of IL-1 $\beta$ (a), MCP-1 (b), TNF $\alpha$ (c), MIP-2 (d), IL-6 (e) and TGF- $\beta$ (f) by ELISA. $(\mathbf{g}-\mathbf{l})$ The mRNA expression of IL-1 $\beta$ (g), MCP-1 (h), TNF $\alpha(\mathbf{i}), \operatorname{MIP}-2(\mathbf{j})$, IL-6 (k) and TGF- $\beta$ (l) was determined by qPCR. The data were presented as mean $\pm \mathrm{SD},{ }^{\# \#} p<0.001$ vs. PBS+DMSO group, ** $p<0.01,{ }^{* * *} p<0.001$ vs. SA+DMSO group, $n=3$.

\subsection{Acetylharpagide Suppresses S. aureus-Induced NF-кB Activity}

The above results indicate that acetylharpagide has anti-inflammatory effects on S. aureus infection. However, the mechanism is still poorly understood. NF- $\mathrm{kB}$ signaling pathways play important roles in inflammatory and immune response [36-38]. Some studies have reported that inhibition of this pathway relieved S. aureus-induced pneumonia and lung injury [39-42]. Since the secretion of cytokines requires nuclear translocation of the transcription factor NF- $\mathrm{B}$, we examined the effects of 
acetylharpagide on NF-кB nuclear translocation. The cytoplasmic and nuclear proteins were collected and western blot was carried out to investigate the expression of p65 in the cytoplasm and nucleus. We found that $S$. aureus infection induced the transfer of p65 from the cytoplasm into the nucleus, whereas acetylharpagide pretreatment reduced this translocation (Figure 6a). To measure the effect of acetylharpagide on the activity of transcription factor NF- $\mathrm{B}, \mathrm{NF}-\kappa \mathrm{B}$ luciferase reporter plasmid was transfected into Raw264.7 cells, and the following S. aureus-induced luciferase activity in the absence or presence of acetylharpagide was detected with the dual-luciferase reporter assay system. The results revealed that acetylharpagide pretreatment significantly decreased the $S$. aureus-induced NF- $\mathrm{kB}$ activity (Figure $6 \mathrm{~b}$ ). Thus, these results suggest that acetylharpagide suppresses S. aureus-induced NF- $\mathrm{kB}$ activity in Raw 264.7 cells.
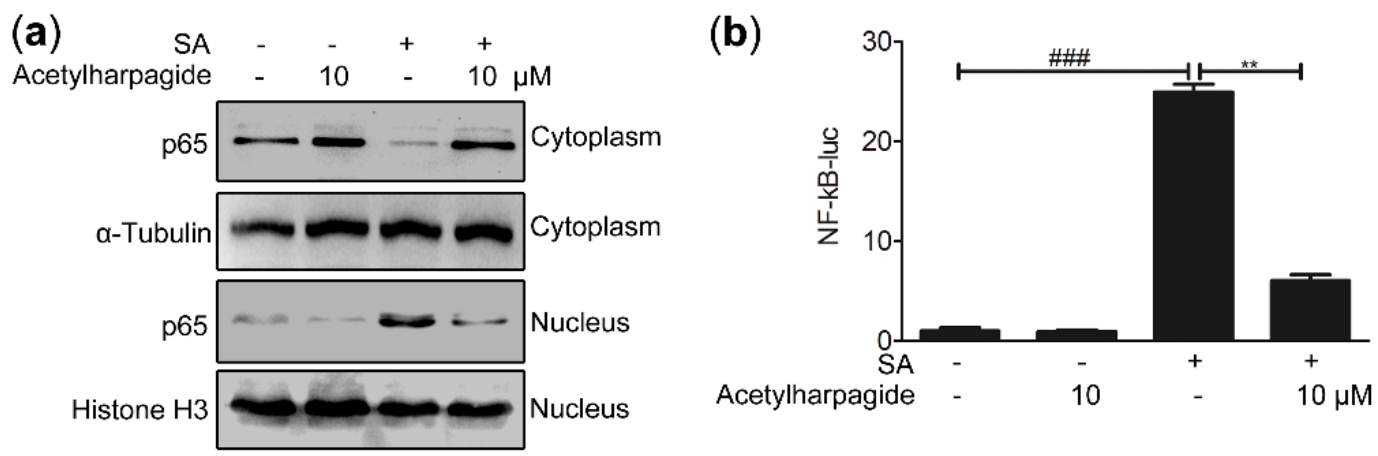

Figure 6. Acetylharpagide suppressed S. aureus (SA)-induced NF- $\kappa$ B activity. (a) Raw264.7 cells were pretreated with acetylharpagide or DMSO for $2 \mathrm{~h}$, then stimulated with $S$. aureus (multiplicity of infection (MOI), 10:1) for $2 \mathrm{~h}$. Nuclear and cytoplasmic proteins were extracted and detected for the expression of p65 by western blot; (b) NF-kB luciferase reporter plasmid was transfected into Raw264.7 cells. After $24 \mathrm{~h}$, cells were stimulated as in A. Luciferase assays were carried out with the dual-luciferase reporter assay system, and the ratio of firefly luminescence to renilla luminescence was evaluated to reflect NF- $\mathrm{kB}$ activity. The relative luciferase activity normalized to the control group is shown. The data were presented as mean \pm SD, ${ }^{\# \#} p<0.001$ vs. PBS+DMSO group, ${ }^{* *} p<0.01$ vs. SA+DMSO group, $n=3$.

\subsection{Acetylharpagide Inhibits the Interaction between Polyubiquitinated RIP1 and NEMO upon S. aureus Infection}

In the resting state, NF- $\mathrm{B}$ was trapped in the cytoplasm by the inhibitory protein $\mathrm{I}_{\kappa} \mathrm{B} \alpha$. Once activated, I $\mathrm{K} B \alpha$ was phosphorylated by $\mathrm{IKK} \beta$ and degraded by $26 \mathrm{~S}$ proteasome, thus releasing NF- $\mathrm{KB}$ to the nucleus, initiating the transcription of inflammatory cytokines and inducing inflammation $[43,44]$. Therefore, we assessed the effect of acetylharpagide on $S$. aureus-induced I $\mathrm{B} \mathrm{B} \alpha$ phosphorylation and degradation. Western blot analysis showed that $S$. aureus elevated the level of $I \kappa B \alpha$ phosphorylation, and the phosphorylated I $\kappa B \alpha$ was then degraded by the $26 S$ proteasome, resulting in a decrease in the level of total $\mathrm{I} \kappa \mathrm{B} \alpha$. However, acetylharpagide pretreatment inhibited the phosphorylation of $I \kappa B \alpha$, thereby inhibiting the degradation of $I \kappa B \alpha$, resulting in an increase in the level of total $\mathrm{I} \kappa \mathrm{B} \alpha$. These results indicate that acetylharpagide pretreatment markedly inhibits S. aureus-induced IкB $\alpha$ phosphorylation and degradation in Raw264.7 cells (Figure 7a). We next studied the target or molecular mechanism by which acetylharpagide regulates NF- $\kappa \mathrm{B}$ signaling. Co-immunoprecipitation results revealed that S. aureus-induced interaction between NEMO and polyubiquitinated RIP1 was inhibited by acetylharpagide pretreatment in Raw264.7 cells (Figure 7b). These results predict that inhibition of the interaction between NEMO and polyubiquitinated RIP1 by acetylharpagide prevents $\mathrm{I} \kappa \mathrm{B} \alpha$ phosphorylation and degradation, and ultimately inhibits NF- $\kappa$ B activity. 

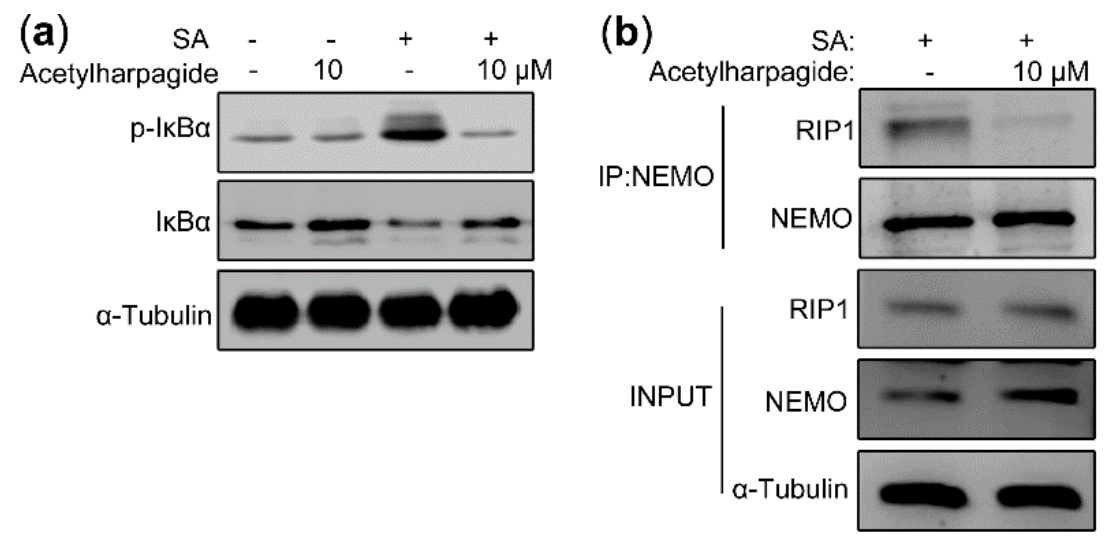

Figure 7. Acetylharpagide inhibited the interaction between polyubiquitinated RIP1 and NEMO upon S. aureus (SA) stimulation. (a) Raw264.7 cells were pretreated with acetylharpagide or DMSO for $2 \mathrm{~h}$, then stimulated with $S$. aureus (multiplicity of infection (MOI), 10:1) for $2 \mathrm{~h}$. The expressions of $\mathrm{I} \kappa \mathrm{B} \alpha$ and phosphorylated $\mathrm{I} \kappa \mathrm{B} \alpha$ in cellular lysates were analyzed by western blot; (b) Raw264.7 cells were stimulated as in A. Cellular lysates were subjected to immunoprecipitation with an anti-NEMO antibody followed by immunoblotting with anti-NEMO and anti-RIP1 antibodies.

\section{Discussion}

S. aureus infections lead to an acute inflammatory response, which clears invading pathogens, repairs damaged tissues and maintains homeostasis $[45,46]$. However, excessive or uncontrolled inflammation would cause or aggravate tissue and organ injury [47]. At present, there are mainly glucocorticoids and nonsteroidal anti-inflammatory drugs, but long-term use of glucocorticoids has serious side effects, such as reducing the body's resistance to pathogenic microorganisms, osteoporosis, epilepsy, etc. [48]. In nonsteroidal anti-inflammatory drugs, non-selective cyclooxygenase (COX) inhibitors would cause serious gastric ulcer complications [49], and selective COX-2 inhibitors would elevate the hazard of cardiovascular disease [50]. Because of these side effects of glucocorticoids and nonsteroidal anti-inflammatory drugs, finding novel treatments against $S$. aureus infections is urgent. Recently, many studies have reported that traditional Chinese medicines can effectively relieve S. aureus-induced inflammation and defend against infections [51-53]. In our study, we found that acetylharpagide, an iridoid glycoside isolated from Ajuga decumbens, attenuated the inflammation in S. aureus-induced ALI by suppressing NF- $\mathrm{KB}$ signaling pathway, thus reducing lung damage and improving the survival of $S$. aureus-infected mice.

ALI mainly presents as lung structural damage, inflammatory cell infiltration and pulmonary edema $[54,55]$. The wet/dry weight ratio is a marker of pulmonary edema. We found that the wet weight of the lungs increased after $S$. aureus infection, but greatly lightened with acetylharpagide treatment, indicating that acetylharpagide could relieve pulmonary edema effectually. In addition, MPO activity, a marker indicating neutrophil infiltration, was elevated in S. aureus-infected mice, but significantly decreased by acetylharpagide treatment, suggesting that acetylharpagide could prevent the infiltration of neutrophils in lungs. Furthermore, H\&E staining showed that acetylharpagide pretreatment reduced S. aureus-induced lung structural damage. These results demonstrate that acetylharpagide protects mice from S. aureus-induced ALI.

Cytokines are small molecular polypeptides or glycoproteins secreted by immune cells. A lot of pro-inflammatory cytokines play important roles in regulating immune response and inflammation [56]. In our study, we found $S$. aureus infection triggered severe pneumonia, which caused a great rise in pro-inflammatory factors, such as IL- $1 \beta$, IL-6, TGF- $\beta$, MIP-2, MCP- 1 and TNF- $\alpha$ in bronchoalveolar lavage fluid. However, acetylharpagide pretreatment inhibited $S$. aureus-induced pro-inflammatory cytokines and attenuated S. aureus-induced inflammation.

Macrophages are an essential member of immune cells. They have powerful functions of phagocytosis, migration and secretion of pro-inflammatory cytokines [35]. Therefore, Raw264.7 murine 
macrophages were used in vitro to investigate the activity and mechanism of acetylharpagide on S. aureus infection. In our study, Raw264.7 cells were pretreated with acetylharpagide or DMSO followed by $S$. aureus infection. The culture medium was harvested for determining the concentration of cytokines. ELISA results revealed that $S$. aureus-induced cytokines IL- $1 \beta$, MCP-1, TNF- $\alpha$, MIP-2, IL-6 and TGF- $\beta$ were decreased by acetylharpagide pretreatment. Consistently, acetylharpagide pretreatment inhibited the mRNA expression of these pro-inflammatory factors. These results predict that acetylharpagide inhibits the secretion of pro-inflammatory factors that is induced by $S$. aureus in macrophages.

The canonical NF- $\mathrm{B}$ signaling pathway, which plays important roles in inflammation and immune response, has been considered a valuable target for drug design [36-38]. Because of the several levels, NF- $\kappa B$ signaling pathway can be targeted at multiple points including phosphatase, ubiquitination, nuclear translocation, DNA binding, protein acetyltransferase and methyltransferase [57]. Some studies have shown that many drugs inhibit the NF- $\mathrm{kB}$ signaling pathway by inhibiting the phosphorylation of $\mathrm{I} \kappa \mathrm{B}$ or the nuclear transport of $\mathrm{p} 65[58,59]$. In our study, we found S. aureus-induced $\mathrm{I} \kappa \mathrm{B} \alpha$ phosphorylation and p65 translocation from the cytoplasm into the nucleus were reduced by acetylharpagide pretreatment. In addition, $S$. aureus-induced luciferase activity of NF- $\kappa \mathrm{B}$ reporter plasmid was also reduced by acetylharpagide pretreatment.

In the canonical NF- $\mathrm{BB}$ signaling pathway, once the ligands, such as lipopolysaccharide or cytokines, bind to the related receptor, it will cause a configuration change in the latter, and induce the polyubiquitination of RIP1 at Lys-377. This polyubiquitin chains act as a scaffold to recruit TAK1 and IKK complexes via their adaptor proteins TAB2/3 and NEMO, respectively [60,61]. After that, TAK1 phosphorylates IKK $\beta$ and activates the IKB kinase IKK, which phosphorylates the inhibitor of NF- $\kappa B(I \kappa B)$ and makes its $26 S$ proteasome degrade, thus releasing NF- $\kappa B$ to the nucleus to start up the expression of target genes, such as inflammatory cytokines $[43,44]$. Therefore, the interaction of NEMO and RIP1 is indispensable for the activation of the NF-KB signaling pathway. Blocking the binding of NEMO to polyubiquited RIP1 could inhibit the activation of IKK [62-64]. In this study, we found the interaction between polyubiquitinated RIP1 and NEMO induced by S. aureus infection was inhibited by acetylharpagide pretreatment in Raw264.7 cells. Thus, acetylharpagide inhibits the activity of NF-kB upon S. aureus infection by blocking polyubiquitinated RIP1 and NEMO interaction, but the mechanism needs further study.

\section{Materials and Methods}

\subsection{Chemicals and Reagents}

Six to eight week-old male C57BL6 mice (weight: 18-22 g) were obtained from the model animal research center of Nanjing University (Nanjing, China). Raw264.7 cell line (TIB-71) and USA300 (BAA-1717) were purchased from American Type Culture Collection (Manassas, VA, USA). RPMI1640 medium and lipofectamine 3000 were purchased from Thermo Scientific (Waltham, MA, USA). Penicillin-streptomycin solution, Ethylene Diamine Tetraacetic Acid (EDTA)-trypsin, dimethyl sulfoxide side (DMSO), wright stain, hematoxylin-eosin stain kit and nuclear protein extraction kit were purchased from Solarbio (Beijing, China). Acetylharpagide (CAS No. 6926-14-3, Item No. S9474) was purchased from Selleck (Houston, TX, USA). Polyvinylidene difluoride (PVDF) membrane and protein A/G agarose slurry were purchased from Millipore (Billerica, MA, USA). Evans blue dye was purchased from Sigma-Aldrich (St. Louis, MO, USA). Enzyme-linked immunosorbent assays (ELISA) kits were purchased from R\&D (Minneapolis, MN, USA). P65, IкB $\alpha$, phospho IkB $\alpha$, NEMO, RIP1, $\alpha$-tubulin and Histone H3 antibodies were purchased from Proteintech Group (Chicago, IL, USA). Dual-luciferase reporter assay system was purchased from Promega (Madison, WI, USA). TransStart Green qPCR SuperMix was purchased from TransGene Biotechnology (Beijing, China). Cell lysis buffer was purchased from Beyotime Biotechnology (Shanghai, China). Trizol reagent was purchased from Invitrogen (Carlsbad, CA, USA). 


\subsection{Animals}

C57BL6 mice were preserved in a sterilized standard cage at $25{ }^{\circ} \mathrm{C}$ under a regular $12 / 12 \mathrm{~h}$ light and dark cycle, and supplied food and water randomly.

USA300 were cultivated in tryptic soy broth (TSB) medium overnight at $37{ }^{\circ} \mathrm{C}$, and then re-inoculated into new TSB medium at 10:1. When it reached the logarithmic phase, pelleted and resuspended in phosphate buffered saline (PBS) to $1 \times 10^{9}$ colony forming units (CFU)/mL. For the lung infection, mice were injected with $4 \%$ chloral hydrate intraperitoneally at a dose of $0.1 \mathrm{~mL} / 10 \mathrm{~g}$ for anesthesia. $2 \times 10^{8} \mathrm{CFU}$ of $S$. aureus or same volume of PBS was slowly dropped into the trachea through a self-made blunt-head syringe. Then kept the mouse upright for 1 min to distribute the bacterial solution evenly on both lungs. The experimental mice were grouped randomly as follows: (1) group PBS: mice were injected intraperitoneally with DMSO $2 \mathrm{~h}$ before PBS infection; (2) group SA: mice were injected intraperitoneally with DMSO $2 \mathrm{~h}$ before $S$. aureus infection; (3) group $5 \mathrm{mg} / \mathrm{kg}$ acetylharpagide + SA: mice were injected intraperitoneally with $5 \mathrm{mg} / \mathrm{kg}$ of acetylharpagide $2 \mathrm{~h}$ before S. aureus infection; (4) group $10 \mathrm{mg} / \mathrm{kg}$ acetylharpagide + SA: mice were injected intraperitoneally with $10 \mathrm{mg} / \mathrm{kg}$ of acetylharpagide $2 \mathrm{~h}$ before S. aureus infection; (5) group $20 \mathrm{mg} / \mathrm{kg}$ acetylharpagide + SA: mice were injected intraperitoneally with $20 \mathrm{mg} / \mathrm{kg}$ of acetylharpagide $2 \mathrm{~h}$ before $S$. aureus infection; (6) group $40 \mathrm{mg} / \mathrm{kg}$ acetylharpagide + SA: mice were injected intraperitoneally with $40 \mathrm{mg} / \mathrm{kg}$ of acetylharpagide $2 \mathrm{~h}$ before $S$. aureus infection. Acetylharpagide was dissolved in DMSO as a stock solution at a concentration of $200 \mathrm{mM}$. For in vivo/animal studies, the stock solution was suspended in sterile saline at a total volume of $200 \mu \mathrm{L}$ per mouse. Taking the maximum concentration of $40 \mathrm{mg} / \mathrm{kg}$ injected into mice (18-22 g) as an example, it took about $10 \mu \mathrm{L}$ of the stock solution to be diluted to $200 \mu \mathrm{L}$, so the final DMSO concentration did not exceed 5\%. Control mice were injected with 5\% DMSO. During the whole experiment, no mice showed obvious abnormal performance. For in vitro assays, the stock solution was suspended in cell culture medium in $2 \mathrm{~mL}$ for each well of a 6-well plate. Taking the maximum concentration of $20 \mu \mathrm{M}$ as an example, it took $0.2 \mu \mathrm{L}$ of stock solution to be diluted to $2 \mathrm{~mL}$ for each well, so the final DMSO concentration did not exceed $0.01 \%$. Control sample was treated with $0.2 \mu \mathrm{L}$ DMSO.

The survival of infected mice was monitored daily. The whole lung was harvested $12 \mathrm{~h}$ after S. aureus infection and homogenized for evaluating bacterial loads and MPO activity. BAL fluid was harvested for examining the concentration of cytokines and total protein, and the number of neutrophils. For lung histomorphology analysis, the lungs were fixed with 4\% paraformaldehyde, dehydrated gradually with gradient ethanol, and then embedded in paraffin. The wax block was sliced with a thickness of $5 \mu \mathrm{m}$, and finally hematoxylin-eosin staining was performed.

The methods were conducted according to the approved guidelines and every effort was made to minimize suffering. All experimental protocols were approved by the Animal Experiment Committee of Nanjing University (SYXK (SU) 2019-0056, 2019.12.16).

\subsection{Western Blot}

Cell culture medium was removed and the cells were washed three times with PBS. $100 \mu \mathrm{L}$ cell lysis buffer was added to each well of a 6-well plate. Cells were lysed on ice for 10 min and moved into a $1.5 \mathrm{~mL}$ centrifuge tube and centrifuged at 12,000 rpm for $10 \mathrm{~min}$, the supernatant were collected and separated by sodium dodecylsulphate polyacrylamide gel electrophoresis. After that, the proteins on the gel were transferred to a PVDF membrane, which was then kept in 5\% skimmed milk for $60 \mathrm{~min}$. Next, the blocked membrane was coated with primary antibodies for $\mathrm{p} 65, \mathrm{I} \kappa \mathrm{B} \alpha$ and phospho $\mathrm{I} \kappa \mathrm{B} \alpha$. It was then washed with phosphate buffered saline tween (PBST) buffer on a shaker for $10 \mathrm{~min}$, and repeated twice. The washed membrane was further coated with a horseradish peroxidase-labeled antibody for $1 \mathrm{~h}$. It was then washed with PBST buffer for $10 \mathrm{~min}$, and repeated twice. Finally, the signal was detected by Tanon chemiluminescence imaging system. 


\subsection{Pulmonary Vascular Permeability and Edema}

Evans blue dye can bind to albumin in plasma. When pulmonary capillaries leak, albumin that is bound to evans blue dye will penetrate into the lung tissue. The amount of evans blue dye in the lung can be measured by chemical colorimetry to reflect the permeability of blood vessels. In brief, mice were injected with $30 \mathrm{mg} / \mathrm{kg}$ of evans blue dye through the tail vein $1 \mathrm{~h}$ before completing the experiment. Once the mice were sacrificed at the indicated times, cardiac perfusion was performed until the outflow was completely clean. The lungs were then removed, immersed in dimethylformamide and kept at $60{ }^{\circ} \mathrm{C}$ for $24 \mathrm{~h}$, and then centrifuged at $12,000 \mathrm{rpm}$ for $30 \mathrm{~min}$. The optical density value of the supernatant was detected at a wavelength of $620 \mathrm{~nm}$ with a spectrophotometer. The evans blue dye concentration is calculated based on its standard curve in dimethylformamide.

The wet/dry weight ratio is assessed to show the lung tissue water content. The lungs were collected and weighed, and this weight was recorded as the wet weight. Then the lungs were placed in $60{ }^{\circ} \mathrm{C}$ for $48 \mathrm{~h}$ and weighed again, and this weight was recorded as dry weight.

\subsection{Cytokines and Neutrophils in BAL Fluid}

To collect BAL fluid, mice were injected with $4 \%$ chloral hydrate intraperitoneally at a dose of $0.1 \mathrm{~mL} / 10 \mathrm{~g}$ for anesthesia. Inserted a self-made blunt-head syringe into the trachea of the mouse and ligated the trachea to prevent the backflow. Gently injected $0.3 \mathrm{~mL}$ of sterile saline, then slowly withdrew. Three times in total. The collected liquid is BAL fluid. BAL fluid was treated with red blood cell lysis buffer and centrifuged at $1000 \mathrm{rpm}$ for $5 \mathrm{~min}$, the supernatant were applied for ELISA to detect the concentration of MIP-2, IL-1 $\beta$, TNF- $\alpha$, IL-6, MCP-1 and TGF- $\beta$. The pellet was resuspended in PBS and the total cell number was counted. The number of neutrophils were counted with wright stain.

\subsection{Bacterial Counts}

The lungs were removed aseptically, weighed and ground with a sterilized tissue grinder in $1 \mathrm{~mL}$ of sterilized PBS. The homogenate was diluted by 10 -fold gradient and serially diluted to $10^{8}$. $100 \mu \mathrm{L}$ of the tissue suspension was smeared on tryptic soy agar medium and kept at $37^{\circ} \mathrm{C}$ for $24 \mathrm{~h}$. Bacteria were counted and calculated as CFU per $g$ of lung.

\subsection{Coimmunoprecipitation Assay}

Cell culture medium was removed and the cells were washed three times with PBS. $500 \mu \mathrm{L}$ cell lysis buffer was added to each $60 \mathrm{~mm}$ dish. Cells were lysed on ice for $10 \mathrm{~min}$ and moved into a $1.5 \mathrm{~mL}$ centrifuge tube and centrifuged at 12,000 rpm for $10 \mathrm{~min}$, the supernatant were collected. For immunoprecipitation, $500 \mu \mathrm{L}$ of the supernatant was matched with $0.5 \mu \mathrm{g}$ of antibody plus $30 \mu \mathrm{L}$ of a $50 \%$ slurry of protein $\mathrm{A} / \mathrm{G}$ agarose at $4{ }^{\circ} \mathrm{C}$ overnight. The precipitation was washed three times with PBS, resuspended in $20 \mu \mathrm{L}$ SDS loading buffer and underwent immunoblotting.

\subsection{Dual Luciferase Reporter Assay}

Raw264.7 cells were transfected with a NF-кB luciferase reporter plasmid and infected with S. aureus as described above. Each sample was co-transfected with $20 \mathrm{ng}$ pRL-TK Renilla luciferase reporter plasmid as a control reporter gene. Dual-luciferase reporter assay system was used to detect the luminescence, and NF-kB activity is presented by the ratio of firefly luminescence to renilla luminescence.

\subsection{Quantitative Real-Time PCR}

This experiment was carried out as previously described [65]. $1 \mathrm{~mL}$ Trizol reagent was added to each well of a 6-well plate. Cells were lysed at room temperature for $5 \mathrm{~min}$, and then moved into a $1.5 \mathrm{~mL}$ centrifuge tube. Then added $200 \mu \mathrm{L}$ chloroform, shook vigorously for $15 \mathrm{~s}$, placed the tube on ice for $3 \mathrm{~min}$, and centrifuged at 12,000 rpm for $10 \mathrm{~min}$. Then aspirated the upper liquid into a new tube, 
added an equal volume of isopropanol, mixed well, placed the tube on ice for $10 \mathrm{~min}$, and centrifuged at $12,000 \mathrm{rpm}$ for $10 \mathrm{~min}$. Discarded the supernatant, added $1 \mathrm{~mL} 75 \%$ alcohol to the tube, and then centrifuged at 12,000 rpm for $5 \mathrm{~min}$. The precipitation was RNA.

Reverse transcriptase was then used to reverse-transcribe the RNA into cDNA, which was then subjected to quantitative PCR with the CFX Connect Real-Time PCR Detection System under the following conditions: $94{ }^{\circ} \mathrm{C}$ for $30 \mathrm{~s}$, then 40 cycles at $94{ }^{\circ} \mathrm{C}$ for $5 \mathrm{~s}$ and $60^{\circ} \mathrm{C}$ for $30 \mathrm{~s}$. The mRNA levels of specific genes were normalized to $\beta$-Actin. The specific primer sequences for IL- $1 \beta, \mathrm{MCP}-1, \mathrm{TNF} \alpha$, MIP-2, IL-6 and TGF- $\beta$ are listed in Supplementary Table S1.

\subsection{Extraction of Cytoplasm and Nuclear Proteins}

Nuclear protein extraction kit was used to separate nuclear and cytoplasmic proteins. Cells were first lysed by plasma protein extraction reagent. Added $100 \mu \mathrm{L}$ plasma protein extraction reagent to each sample. Cells were lysed on ice for $10 \mathrm{~min}$ and centrifuged at 12,000 rpm for $10 \mathrm{~min}$, the supernatant was the cytoplasmic protein and the precipitation was the nucleus. Aspirated the supernatant as completely as possible, then the nucleus was lysed by the nuclear protein extraction reagent. Added $50 \mu \mathrm{L}$ nuclear protein extraction reagent to each sample. The nucleus was lysed on ice for $10 \mathrm{~min}$ and centrifuged at 12,000 rpm for $10 \mathrm{~min}$, the supernatant was the nuclear protein.

\subsection{Statistical Analysis}

Data are expressed as the mean $\pm S D$, and Student's t-test was used to determine the statistically significant differences between mean values. Survival was analyzed using the Kaplan-Meier method and statistical analyses were performed using the log-rank test. ${ }^{*} p<0.05,{ }^{* *} p<0.01,{ }^{* * *} p<0.001$, and not significant, NS $>0.05$.

Supplementary Materials: The following are available online, Table S1: Primer sequences.

Author Contributions: Conceptualization, Z.Z. and W.Y.; methodology, Z.Z. and W.Y.; software, Z.Z.; validation, Y.S.; formal analysis, W.Y.; investigation, Z.Z.; resources, Y.W.; data curation, W.Y.; writing-original draft preparation, Z.Z.; writing—review and editing, Y.W.; visualization, Y.S.; supervision, Y.W.; project administration, Y.W.; funding acquisition, Y.W. All authors have read and agreed to the published version of the manuscript.

Funding: This research was funded by National Natural Science Foundation of China, grant number 81473292, 91540119, 81673462 and 81671939; Six talent peaks project in Jiangsu Province to Y.W., grant number YY-012; Key development project of Jiangsu Province, grant number BE2017712.

Acknowledgments: We thank Zhao Xiaojuan for valuable technical support.

Conflicts of Interest: The authors declare no conflict of interest.

\section{References}

1. Rubenfeld, G.D.; Caldwell, E.; Peabody, E.; Weaver, J.; Martin, D.P.; Neff, M.J.; Stern, E.J.; Hudson, L.D. Incidence and Outcomes of Acute Lung Injury. N. Engl. J. Med. 2005, 353, 1685-1693. [CrossRef] [PubMed]

2. Johnson, E.; Matthay, M.A. Acute Lung Injury: Epidemiology, Pathogenesis, and Treatment. J. Aerosol Med. Pulm. Drug Deliv. 2010, 23, 243-252. [CrossRef] [PubMed]

3. Matthay, M.A.; Ware, L.B.; Zimmerman, G.A. The Acute Respiratory Distress Syndrome. J. Clin. Investig. 2012, 122, 2731-2740. [CrossRef] [PubMed]

4. Dreyfuss, D.; Ricard, J. Acute Lung Injury and Bacterial Infection. Clin. Chest Med. 2005, 26, 105-112. [CrossRef] [PubMed]

5. Archer, G.L. Staphylococcus aureus: A well-armed pathogen. Clin. Infect. Dis. 1998, 26, 1179-1181. [CrossRef] [PubMed]

6. Tong, S.Y.; Davis, J.S.; Eichenberger, E.M.; Holland, T.L.; Fowler, V.G. Staphylococcus aureus infections: Epidemiology, pathophysiology, clinical manifestations, and management. Clin. Microbiol. Rev. 2015, 28, 603-661. [CrossRef]

7. Lowy, F.D. Staphylococcus aureus Infections. N. Engl. J. Med. 2009, 339, 520-532. [CrossRef] 
8. Allen, T.C.; Kurdowska, A. Interleukin 8 and acute lung injury. Arch. Pathol. Lab. Med. 2014, 138, $266-269$. [CrossRef]

9. Krzak, A.; Pleva, M.; Napolitano, L.M. Nutrition therapy for ALI and ARDS. Crit. Care Clin. 2011, 27, 647-659. [CrossRef]

10. Lin, X.; Dean, D.A. Gene therapy for ALI/ARDS. Crit. Care Clin. 2011, 27, 705-718. [CrossRef]

11. Chen, J.; Huang, C.; Chang, H.; Li, P.; Liang, Y.; Deng, J.; Huang, S.; Huang, G. Scutellaria baicalensis ameliorates acute lung injury by suppressing inflammation in vitro and in vivo. Am. J. Chin. Med. 2017, 45, 137-157. [CrossRef] [PubMed]

12. Hsu, H.; Hsiao, P.; Kuo, T.; Chiang, S.; Chen, S.; Chiou, S.; Ling, X.; Liang, M.; Cheng, W.; Houng, J. Antioxidant and anti-inflammatory activities of Lonicera japonica Thunb. var. sempervillosa Hayata flower bud extracts prepared by water, ethanol and supercritical fluid extraction techniques. Ind. Crop. Prod. 2016, 89, 543-549. [CrossRef] [PubMed]

13. Wen, B.; He, R.; Li, P.; Xu, Q.; Lu, Y.; Peng, B.; Li, J. Pharmacokinetics of 8-O-acetylharpagide and harpagide after oral administration of Ajuga decumbens Thunb extract in rats. J. Ethnopharmacol. 2013, 147, 503-508. [CrossRef] [PubMed]

14. Hwang, Y.; Kim, D.; Li, W.; Yang, H.J.; Yim, N.; Ma, J.Y. Anti-inflammatory effects of Forsythia suspensa in dextran sulfate sodium-induced colitis. J. Ethnopharmacol. 2017, 206, 73-77. [CrossRef] [PubMed]

15. Nanjing University of Traditional Chinese Medicine. Dictionary of Chinese Materia Medica, 2nd ed.; Shanghai Science and Technology Publishing House: Shanghai, China, 2006; pp. 1035-1037.

16. Ni, B.; Dong, X.; Fu, J.; Yin, X.; Lin, L.; Xia, Z.; Zhao, Y.; Xue, D.; Yang, C.; Ni, J. Phytochemical and biological properties of Ajuga decumbens (Labiatae): A review. Trop. J. Pharm. Res. 2015, 14, 1525-1536. [CrossRef]

17. Olatunde, O.Z.; Yang, Y.; Yong, J.; Lu, C. Advance of the Chemical Components and Biological Activities of Ajuga Decumbens Thunb. Biomed. J. Sci. Tech. Res. 2019, 5, 1-8.

18. Breschi, M.C.; Martinotti, E.; Catalano, S.; Flamini, G.; Morelli, I.; Pagni, A.M. Vasoconstrictor activity of 8-O-acetylharpagide from Ajuga reptans. J. Nat. Prod. 1992, 55, 1145-1148. [CrossRef]

19. Konoshima, T.; Takasaki, M.; Tokuda, H.; Nishino, H. Cancer chemopreventive activity of an iridoid glycoside, 8-acetylharpagide, from Ajuga decumbens. Cancer Lett. 2000, 157, 87-92. [CrossRef]

20. You, Y.; Wang, J.; Tong, Y.; Hao, Q.; Li, Y.; Yang, H.; Huang, L.; Liao, F. Anti-inflammatory effect of acetylharpagide demonstrated by its influence on leukocyte adhesion and transmigration in endothelial cells under controlled shear stress. Clin. Hemorheol. Microcirc. 2014, 56, 205-217. [CrossRef]

21. Xie, Z.Y.; Qin, M.Z.; Fang, Y.L. The pharmacological activity of 8-O-acetylharpagide. World Notes Plant Med. 2005, 20, 56-58.

22. Chen, J.; Wu, H.; Li, H.; Hu, S.; Dai, M.; Chen, J. Anti-inflammatory effects and pharmacokinetics study of geniposide on rats with adjuvant arthritis. Int. Immunopharmacol. 2015, 24, 102-109. [CrossRef] [PubMed]

23. He, Y.; Zhu, S.; Ge, Y.; Kazuma, K.; Zou, K.; Cai, S.; Komatsu, K. The anti-inflammatory secoiridoid glycosides from Gentianae Scabrae Radix: The root and rhizome of Gentiana scabra. J. Nat. Med. 2015, 69, 303-312. [CrossRef] [PubMed]

24. Wang, L.; Liu, X.H.; Chen, H.; Chen, Z.Y.; Weng, X.D.; Qiu, T.; Liu, L. Picroside ii protects rat kidney against ischemia/reperfusion-induced oxidative stress and inflammation by the tlr4/nf-kb pathway. Exp. Ther. Med. 2015, 9, 1253-1258. [CrossRef] [PubMed]

25. Hu, H.; Wang, C.; Jin, Y.; Meng, Q.; Liu, Q.; Liu, Z.; Liu, K.; Liu, X.; Sun, H. Catalpol inhibits homocysteine-induced oxidation and inflammation via inhibiting nox4/nf-kb and grp78/perk pathways in human aorta endothelial cells. Inflammation 2019, 42, 64-80. [CrossRef] [PubMed]

26. Zhang, L.; Zhu, T.; Qian, F.; Xu, J.; Dorje, G.; Zhao, Z.; Guo, F.; Li, Y. Iridoid glycosides isolated from Scrophularia dentata Royle ex Benth. and their anti-inflammatory activity. Fitoterapia 2014, 98, 84-90. [CrossRef]

27. Zhu, W.; Pang, M.; Dong, L.; Huang, X.; Wang, S.; Zhou, L. Anti-inflammatory and immunomodulatory effects of iridoid glycosides from Paederia scandens (LOUR.) MERRILL (Rubiaceae) on uric acid nephropathy rats. Life Sci. 2012, 91, 369-376. [CrossRef]

28. Li, M.; Shang, X.; Zhang, R.; Jia, Z.; Fan, P.; Ying, Q.; Wei, L. Antinociceptive and anti-inflammatory activities of iridoid glycosides extract of Lamiophlomis rotata (Benth.) Kudo. Fitoterapia 2010, 81, 167-172. [CrossRef]

29. Yu, B.; Shen, Y.; Qiao, J.; Cui, Q. Geniposide attenuates Staphylococcus aureus-induced pneumonia in mice by inhibiting NF-kB activation. Microb. Pathog. 2017, 112, 117-121. [CrossRef] 
30. He, J.; Li, J.; Liu, H.; Yang, Z.; Zhou, F.; Wei, T.; Dong, Y.; Xue, H.; Tang, L.; Liu, M. Scandoside exerts anti-inflammatory effect via suppressing NF- $\mathrm{KB}$ and MAPK signaling pathways in LPS-Induced RAW 264.7 macrophages. Int. J. Mol. Sci. 2018, 19, 457. [CrossRef]

31. Liang, H.; Zhang, L.; Wang, H.; Tang, J.; Yang, J.; Wu, C.; Chen, S. Inhibitory Effect of Gardenoside on Free Fatty Acid-Induced Steatosis in HepG2 Hepatocytes. Int. J. Mol. Sci. 2015, 16, 27749-27756. [CrossRef]

32. West, J.B. Thoughts on the pulmonary blood-gas barrier. Am. J. Physiol.-Lung Cell. Mol. Physiol. 2003, 285, L501-L513. [CrossRef] [PubMed]

33. Mantovani, A.; Cassatella, M.A.; Costantini, C.; Jaillon, S. Neutrophils in the activation and regulation of innate and adaptive immunity. Nat. Rev. Immunol. 2011, 11, 519-531. [CrossRef] [PubMed]

34. Nathan, C. Neutrophils and immunity: Challenges and opportunities. Nat. Rev. Immunol. 2006, 6, $173-182$. [CrossRef]

35. Fujiwara, N.; Kobayashi, K. Macrophages in inflammation. Curr. Drug Targets 2005, 4, 281-286. [CrossRef] [PubMed]

36. Liu, T.; Zhang, L.; Joo, D.; Sun, S.C. NF-кB signaling in inflammation. Signal Transduct. Target. Ther. 2017, 2, 1-9. [CrossRef]

37. Wullaert, A.; Bonnet, M.C.; Pasparakis, M. NF-кB in the regulation of epithelial homeostasis and inflammation. Cell Res. 2011, 21, 146-158. [CrossRef]

38. Silverman, N.; Maniatis, T. NF-кB signaling pathways in mammalian and insect innate immunity. Genes Dev. 2001, 15, 2321-2342. [CrossRef]

39. Yu, B.; Qiao, J.; Shen, Y.; Li, L. Protective effects of tenuigenin on Staphylococcus aureus-induced pneumonia in mice. Microb. Pathog. 2017, 110, 385-389. [CrossRef]

40. Xu, F.; Diao, R.; Liu, J.; Kang, Y.; Wang, X.; Shi, L. Curcumin attenuates staphylococcus aureus-induced acute lung injury. Clin. Respir. J. 2015, 9, 87-97. [CrossRef]

41. Liu, Y.; Wu, H.; Nie, Y.; Chen, J.; Su, W.; Li, P. Naringin attenuates acute lung injury in LPS-treated mice by inhibiting NF-кB pathway. Int. Immunopharmacol. 2011, 11, 1606-1612. [CrossRef]

42. Zhu, T.; Wang, D.; Zhang, W.; Liao, X.; Guan, X.; Bo, H.; Sun, J.; Huang, N.; He, J.; Zhang, Y.; et al. Andrographolide protects against LPS-induced acute lung injury by inactivation of NF-kB. PLoS ONE 2013, 8, e56407. [CrossRef]

43. Delhase, M.; Hayakawa, M.; Chen, Y.; Karin, M. Positive and negative regulation of IкB kinase activity through IKK $\beta$ subunit phosphorylation. Science 1999, 284, 309-313. [CrossRef] [PubMed]

44. Baldwin, A.S. The NF-кB and IкB proteins: New discoveries and insights. Annu. Rev. Immunol. 1996, 14, 649-681. [CrossRef] [PubMed]

45. Pollitt, E.J.; Szkuta, P.; Burns, N.; Foster, S.J. Staphylococcus aureus infection dynamics. PLoS Pathog. 2018, 14, e1007112. [CrossRef]

46. Newton, K.; Dixit, V.M. Signaling in Innate Immunity and Inflammation. Cold Spring Harbor Perspect. Biol. 2012, 4, a006049. [CrossRef] [PubMed]

47. Lin, S.; Wu, H.; Wang, C.; Xiao, Z.; Xu, F. Regulatory T Cells and Acute Lung Injury: Cytokines, Uncontrolled Inflammation, and Therapeutic Implications. Front. Immunol. 2018, 9, 1545-1554. [CrossRef]

48. Oray, M.; Abu Samra, K.; Ebrahimiadib, N.; Meese, H.; Foster, C.S. Long-term side effects of glucocorticoids. Expert Opin. Drug Saf. 2016, 15, 457-465. [CrossRef]

49. Lanza, F.L. A review of gastric ulcer and gastroduodenal injury in normal volunteers receiving aspirin and other non-steroidal anti-inflammatory drugs. Scand. J. Gastroenterol. 1989, 163, 24-31. [CrossRef]

50. Wong, M.; Chowienczyk, P.; Kirkham, B. Cardiovascular issues of COX-2 inhibitors and NSAIDs. Aust. Fam. Physician 2005, 34, 945-948.

51. Chen, X.; Shang, F.; Meng, Y.; Li, L.; Cui, Y.; Zhang, M.; Qi, K.; Xue, T. Ethanol extract of Sanguisorba officinalis L. inhibits biofilm formation of methicillin-resistant Staphylococcus aureus in an ica-dependent manner. J. Dairy Sci. 2015, 98, 8486-8491. [CrossRef]

52. Jiang, X.; Wang, Y.; Qin, Y.; He, W.; Benlahrech, A.; Zhang, Q.; Jiang, X.; Lu, Z.; Ji, G.; Zheng, Y. Micheliolide provides protection of mice against Staphylococcus aureus and MRSA infection by down-regulating inflammatory response. Sci. Rep. 2017, 7, 41964. [CrossRef] [PubMed]

53. Wang, J.; Zhou, X.; Li, W.; Deng, X.; Deng, Y.; Niu, X. Curcumin protects mice from Staphylococcus aureus pneumonia by interfering with the self-assembly process of $\alpha$-hemolysin. Sci. Rep. 2016, 6, 28254. [CrossRef] [PubMed] 
54. Mokra, D.; Kosutova, P. Biomarkers in acute lung injury. Respir. Physiol. Neurobiol. 2015, 209, 52-58. [CrossRef] [PubMed]

55. Abraham, E. Neutrophils and acute lung injury. Crit. Care Med. 2003, 31, S195. [CrossRef] [PubMed]

56. Dinarello, C.A. Proinflammatory cytokines. Chest 2000, 118, 503-508. [CrossRef]

57. Gupta, S.C.; Sundaram, C.; Reuter, S.; Aggarwal, B.B. Inhibiting NF-kB activation by small molecules as a therapeutic strategy. BBA-Gene Regul. Mech. 2010, 1799, 775-787. [CrossRef]

58. Koo, T.H.; Lee, J.H.; Park, Y.J.; Hong, Y.S.; Kim, H.S.; Kim, K.W.; Lee, J.J. A sesquiterpene lactone, costunolide, from magnolia grandiflora inhibits nf-kb by targeting ikb phosphorylation. Planta Med. 2001, 67, 103-107. [CrossRef]

59. Greiner, J.F.W.; Müller, J.; Zeuner, M.T.; Hauser, S.; Seidel, T.; Klenke, C.; Grunwald, L.M.; Schomann, T.; Widera, D.; Sudhoff, H.; et al. 1,8-cineol inhibits nuclear translocation of nf-kb p65 and nf-kb-dependent transcriptional activity. BBA Mol. Cell Res. 2013, 1833, 2866-2878. [CrossRef]

60. Wertz, I.E.; Dixit, V.M. Signaling to NF-кB: Regulation by Ubiquitination. Cold Spring Harbor Perspect. Biol. 2010, 2, a003350. [CrossRef]

61. Ea, C.K.; Deng, L.; Xia, Z.P.; Pineda, G.; Chen, Z.J. Activation of ikk by tnfalpha requires site-specific ubiquitination of rip1 and polyubiquitin binding by nemo. Mol. Cell 2006, 22, 245-257. [CrossRef]

62. Wu, C.; Conze, D.B.; Li, T.; Srinivasula, S.M.; Ashwell, J.D. Sensing of Lys 63-linked polyubiquitination by NEMO is a key event in NF-kB activation. Nat. Cell Biol. 2006, 8, 398-406. [CrossRef]

63. Bist, P.; Leow, S.C.; Phua, Q.H.; Shu, S.; Zhuang, Q.; Loh, W.T.; Nguyen, T.H.; Zhou, J.; Hooi, S.C.; Lim, L. Annexin-1 interacts with NEMO and RIP1 to constitutively activate IKK complex and NF- $\mathrm{KB}$ : Implication in breast cancer metastasis. Oncogene 2011, 30, 3174-3185. [CrossRef] [PubMed]

64. Odonnell, M.A.; Hase, H.; Legarda, D.; Ting, A.T. NEMO inhibits programmed necrosis in an NFkB-independent manner by restraining RIP1. PLoS ONE 2012, 7, e41238. [CrossRef] [PubMed]

65. Guo, W.; Sun, Y.; Liu, W.; Wu, X.S.; Guo, L.; Cai, P.; Shen, Y.; Shu, Y.; Gu, Y.; Xu, Q. Small molecule-driven mitophagy-mediated NLRP3 inflammasome inhibition is responsible for the prevention of colitis-associated cancer. Autophagy 2014, 10, 972-985. [CrossRef] [PubMed]

Sample Availability: Samples are not available from the authors.

Publisher's Note: MDPI stays neutral with regard to jurisdictional claims in published maps and institutional affiliations.

(C) 2020 by the authors. Licensee MDPI, Basel, Switzerland. This article is an open access article distributed under the terms and conditions of the Creative Commons Attribution (CC BY) license (http://creativecommons.org/licenses/by/4.0/). 